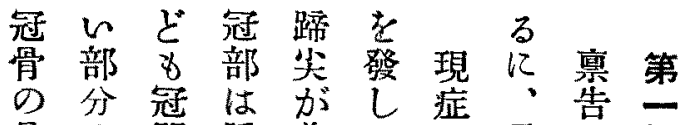
骨 の關湩着全最例 折 鏠篩 脤地了患後本 加壓の、す着馬に馬想 或に迴溫る地は至は惠 は際轉熱とせ體 b五號 冠し運范急守格飛月 關著動有激稍大越四鹿冠 節奛老しに高: 白毛 又な試: 擧擧柴同練 は疼み指上し勢時兵七

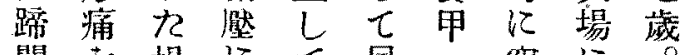
關艺場にて居突に 節 感合龁如方, 被然於折 のずがし何、毛右て 轉る最七に試光前坐 据・活過为江潀 0 素 で反顯敏激步薄重の 忍之著で痛行有度如

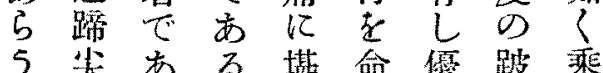
5 尖ある堪命想跛乘

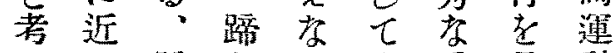
人心蹻方心文乘呈動 て 部 鉗前樣患馬し走 レ分子後子肢で患行 ンのの・をはあ肢的 卜鉗檢左专全るは終 午壓查右るく全り ンのにに! 負全全に 檢場於捻觸重身着障 查合 $て$ 轉診せを地碍

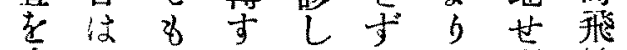
䨘疼陽るて三發す越 施痛性亡見肢汗”練 た非あ何亡飛文つ㕷

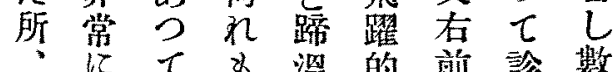

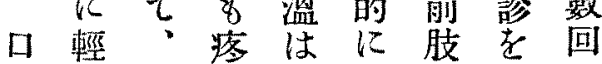

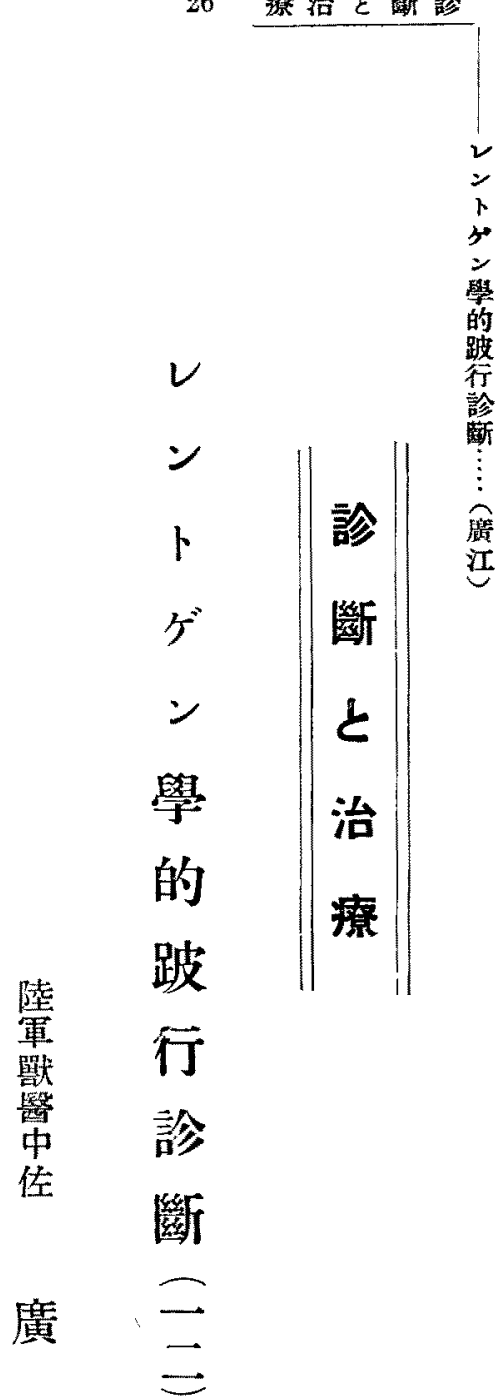
繪減特痛非步は它の のすに常行瘦公飛

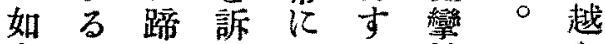
豫依冠部分高当性行 想つ们時撞部 通て近れ㩍に塮た

江 


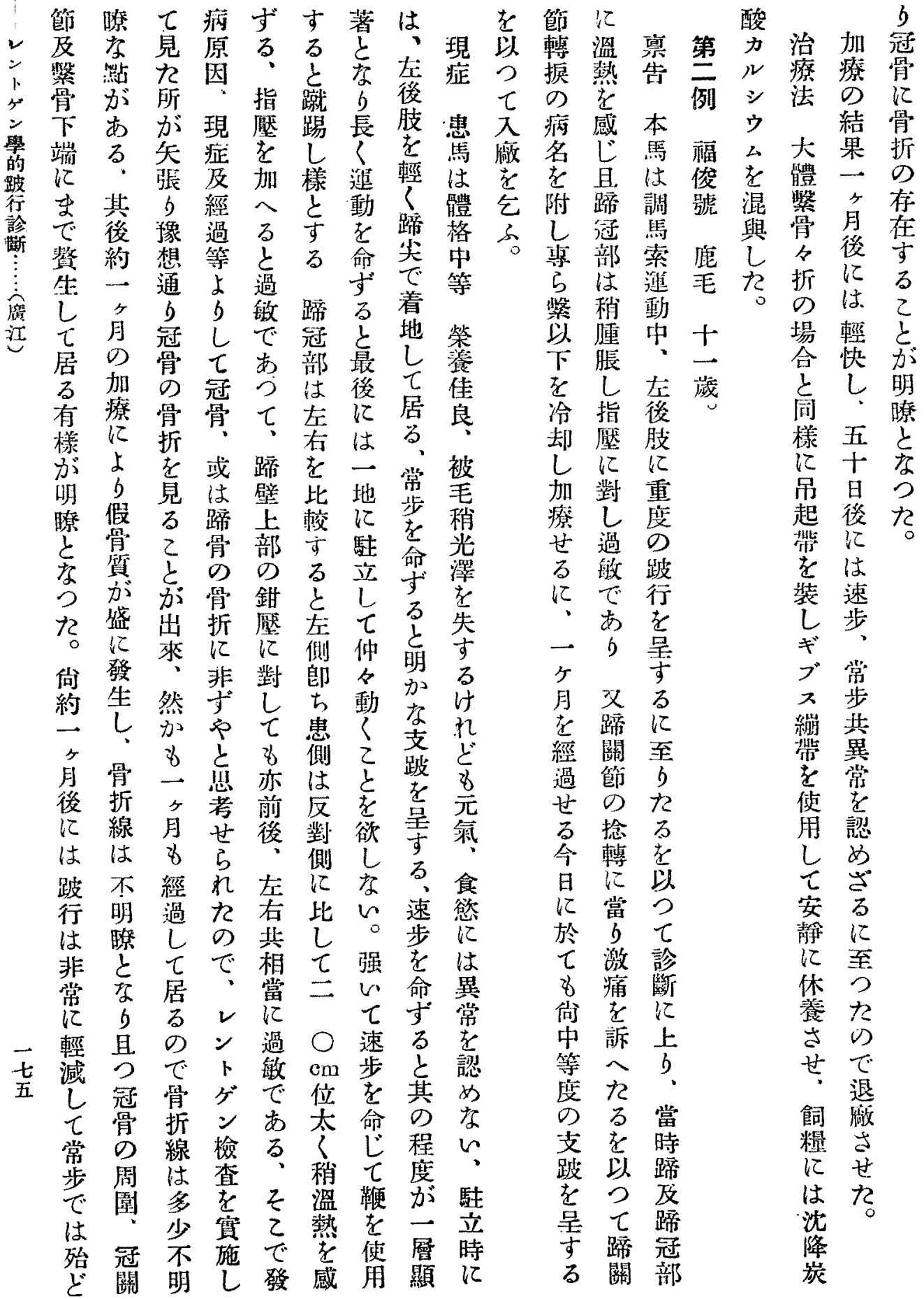


食 の療 骨

を治でに咓こ豫はあ市し症

立

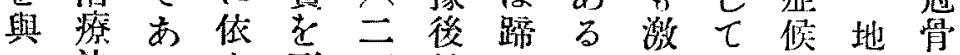

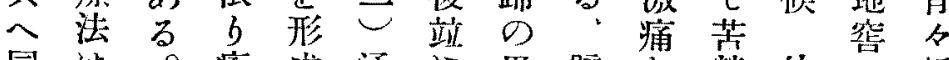

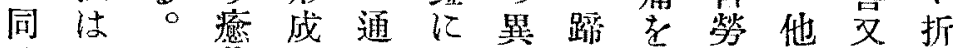

時一着晋常治常鉜訴しのはは

に般しる同療淹子人滑枕熬

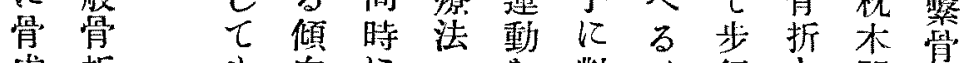

成 折

8 向 に

\section{を 對}

多に冠馬招し及河に折

分 $の$

之等

交則

の し 篩 起

るに

へ 倣

¿

場 ¿及具

カ $\tau$

合之䠙

はと關折

可

で度部 $の$ L

ル吊

冠 万節は㟧

あには支障不

シ 起

夙繁

す

空折

る 柡 肢程

節乙損 治

ウ 縕

台

装

混 ᄂ

與

考

す ギ

ベ ブ

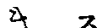

人折 寸 囀

は端る䠙

它端

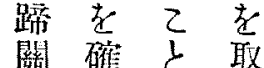

あ贾

篩 䁈 万

る㕛

副骨之克

水質と短

を贅等 小理

用生をの 由

Us及揚骨は

收げはこ

需縮る骨二

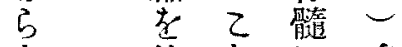

安伴文に多

靜的吕之發

休不出し性

養治棑号骨

むのる交折

せ 跛方故衣

る 行数に成

更考 5

他遺月規易

滋守の文

養

治假之

依腫杜碍

七つ脹肢飛樣

注てし跛越穴

意塊溫行市

す㗶熱を其る

狆音应频他

ば或有發蹄 原

蹄はしし起因

狊被指て 蹋 は

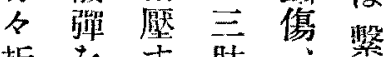

折をす肢

の盐 万蹈

場つと創各

合れ非で等折

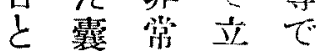

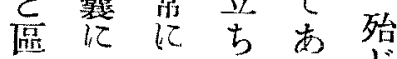

別觸疼 つ

する痛强 $て$

万如艾弪樣

事了訴步骨て

がザへ行折あ

出りる花文

$\tau$

棑了命は

る〈又寸゙症失

高公關当裂

切支

所治 神 跛

療術を市

法を呈

行世采

見第出學

一元る跛

例 退程 行

杗敞度馀

同さに

漛せ岂

付快

算

復

略

。 然

然

速

步

に

於

$\tau$

は.

依

然

ל

$\tau$

輕

度

の

支

跛

茥

专

る

の-

蕞六

度及篩等生顛

後

の音の肢ず倒

骨党捻でる

手

折感䟅 飛

段

のずに躍

然

場る當狀等

駐 
㜣治々瞇診 29

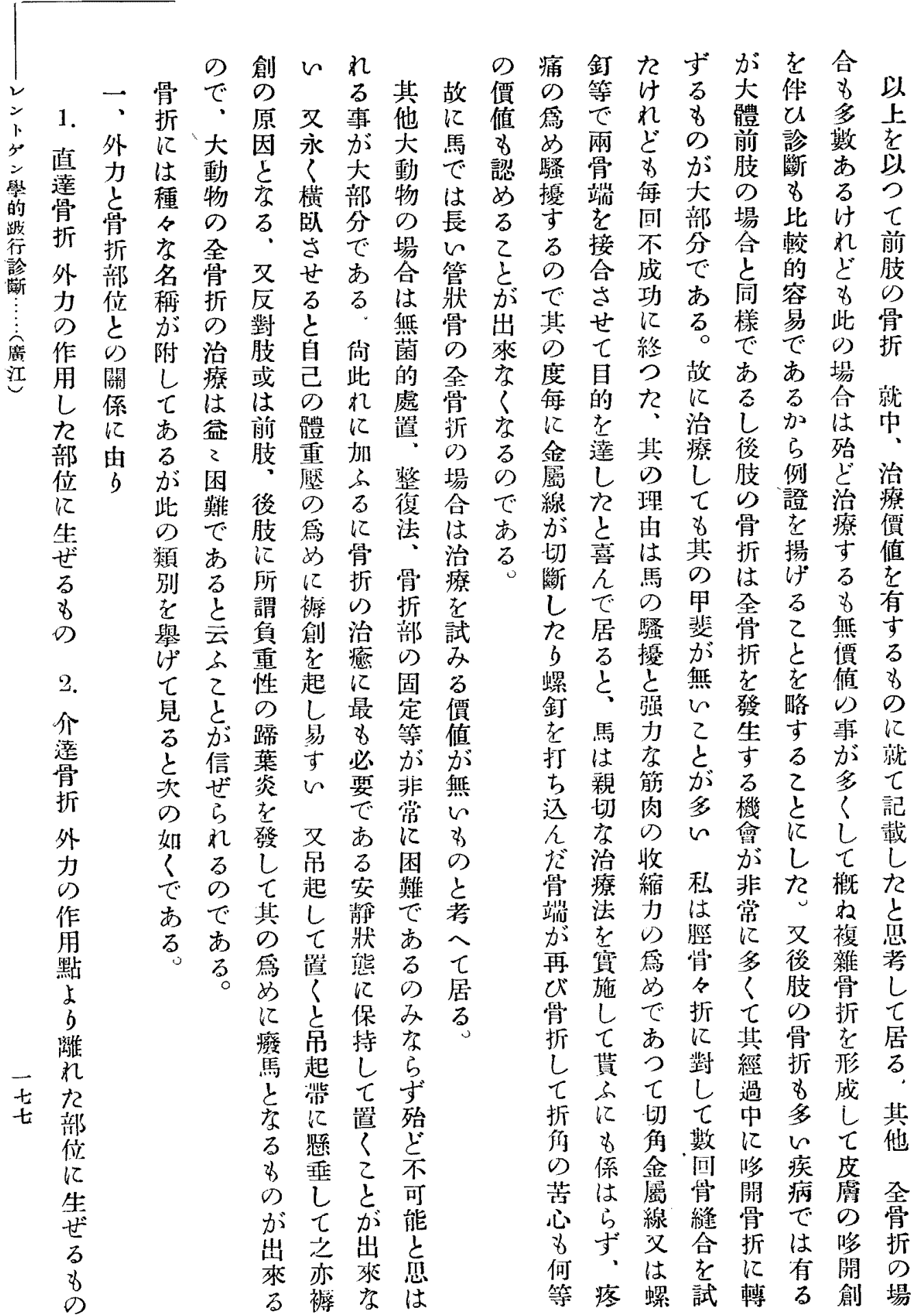




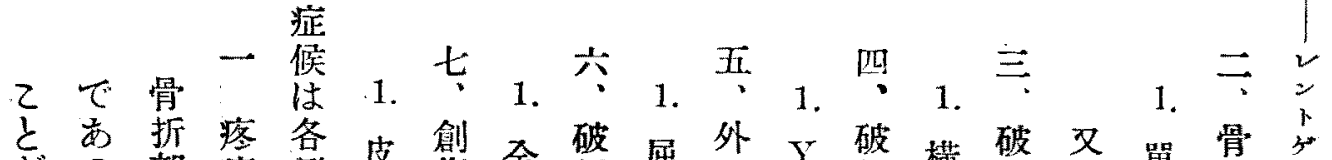

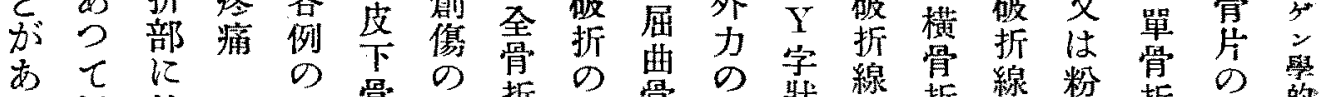

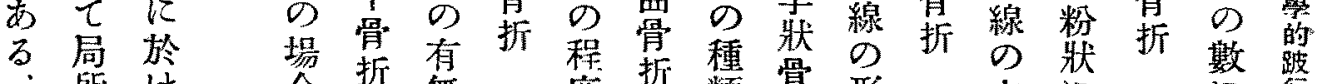
·所

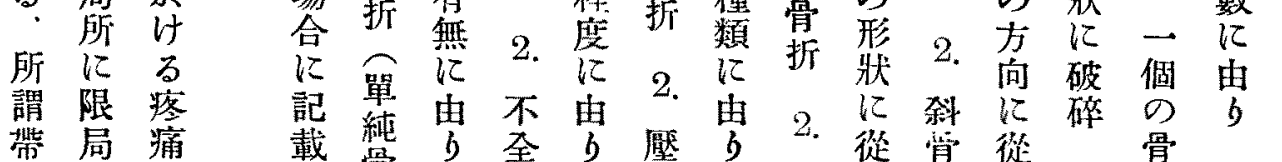

痛しは

線石常

公疼劇

乙骨折骨迫 $\mathrm{T}$ 行折

及 師 甚

のちで

は骨あ

之折る

和痛 加

で孝ら

あ認患

るめ 馬

る は

之 永

占

出重

桃 度

るの

又跛

時 类

呈

はす

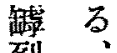
哲折骷字

け 2

亡゙哆

蠦

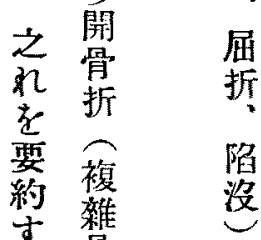

線 指

に 壓

沿 K

页對

$\tau L$

線

狀 8

$k$ 極

現 め

はて

銳

る 敏

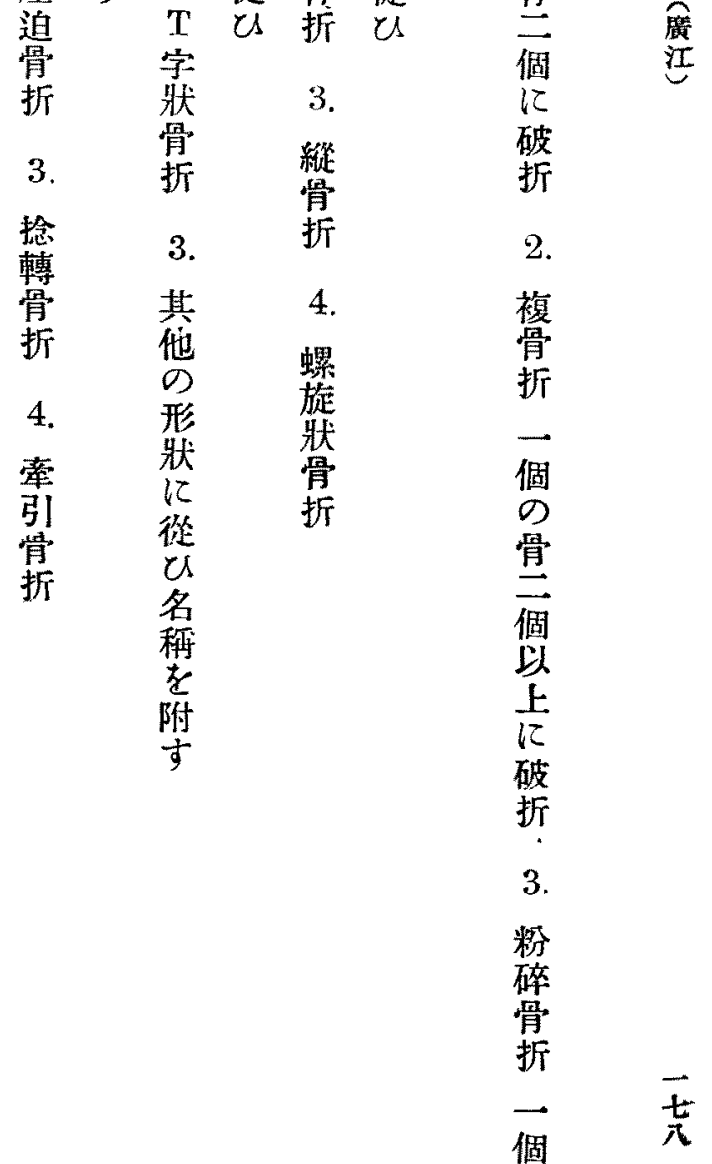




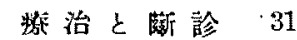

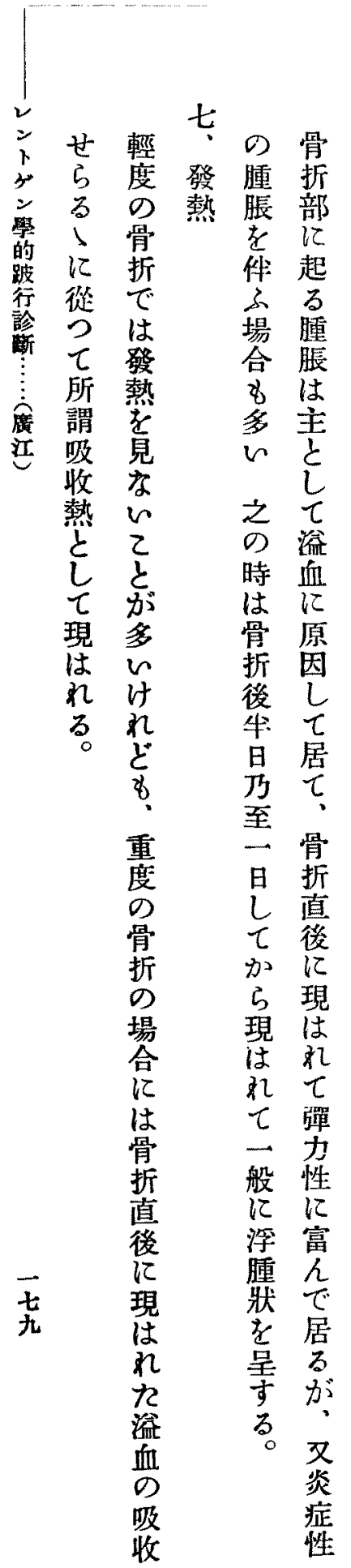

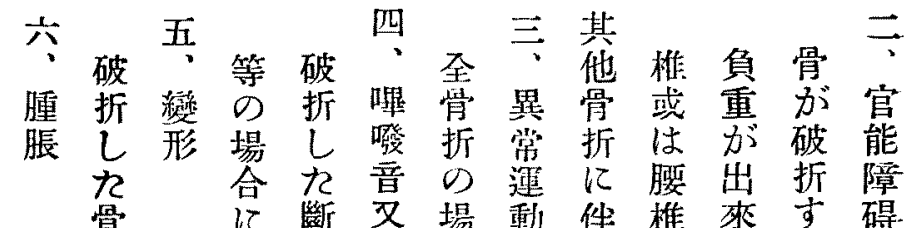

は端は合分のなる

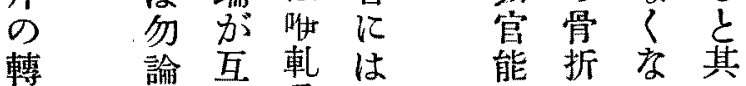

位發に音負障のるる

飞相重碍場、支

依索摩時は合又撑

万擦或種に時性

$\tau$

種

乙 は

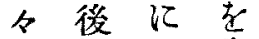

雜軀 は失

發働 多架神已

な 卞性尔麻經筋

る運市祜老肉

意動るて壓は

あ 際起しの

2 ᄂ 立或固

七不は定

能 薩 點

不種

全異

骨裳

折里

或運

は動

新㟧生

端告

離 る

に引を

陷守失

入るふ

万加

加5

如 霓

) 患

は麽部

之裨の

礼症自

で牀動

あを的

又

は

軟

る伴 運

○動

組

織

s

其

間

に

乙は

占全

あ 不

る 可

介

在

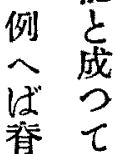




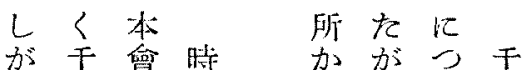

下栠老下战、集

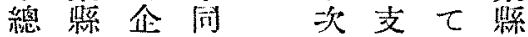

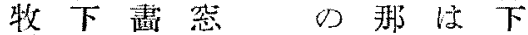

場 總 $し$ 各發留先總

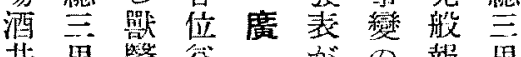

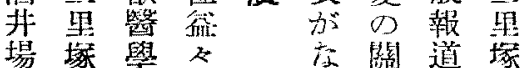

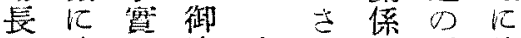

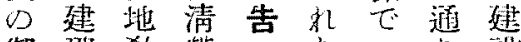

御碑 敎策

好 $の$ 者奉

意件五留

上 俪 生 候

b) L. 地 陫

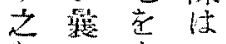

声御永胙

里筫 $儿$ 年

塚同記千

○急一

區仰专月

會ぎべ中
た $一$ b詨

㭙筫す

で維分 今゙

揭切老き

践老二獸

士 延 般 箘

学期血

L. 㕝 科

同集生

募 中

金で紀

橐す念

務つ碎
当 長

磪 期以

笽 間上

に 不記 嗞

診明載

得 の L

亦高 た

万落 諸

に $\sigma$ 種

は跛 ひ

$\checkmark$ 行 症

ンを候

卜龺 愺

ダす 中

ンる盈

線場 折

古命痛

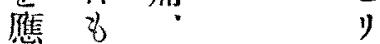

用 前嶵

才 数 㗶

万回 音

に

勝 互 黑

D 5 常

た 記 涉

8 韯 動

の L㚣

はた び

な梂 骨

的片

D注 轌

で意位

あ死等

万要 は

す 磪

万診

姃走

倠 F

です

あ重

万 要

之市

柋症

及 渎

然市

学る。

骨

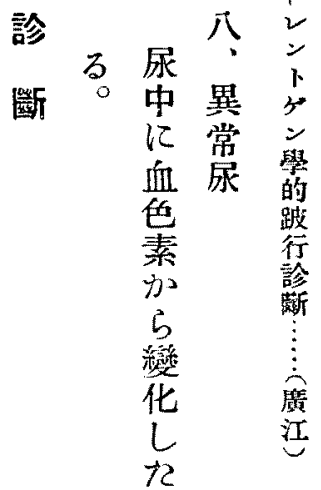

ウ

p

ビ

ン

tr

證

明

t

る

2

$\sum_{n}^{\prime}$

あ

乌.

又

脂

肪

蛋

白

圓

德

等

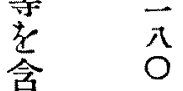

有

務 
圖附「斷診行跛的學ンドトンレ」文論氏汇廣

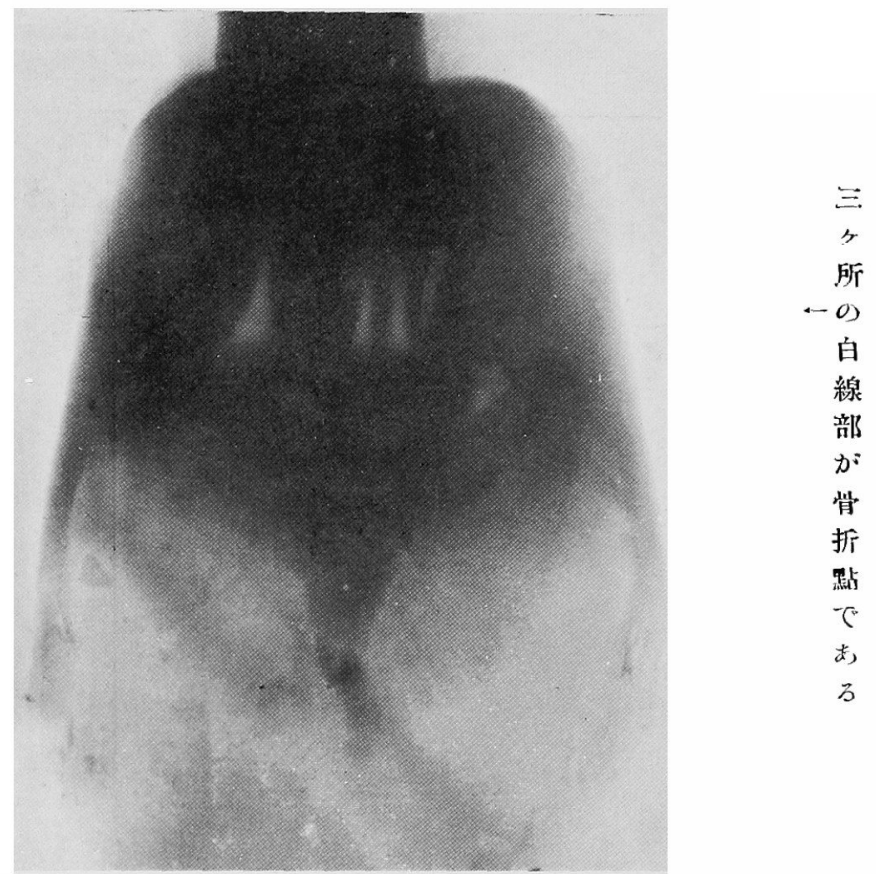

(1) 圖附「病疾音家と生衛㴪公」交論氏本山

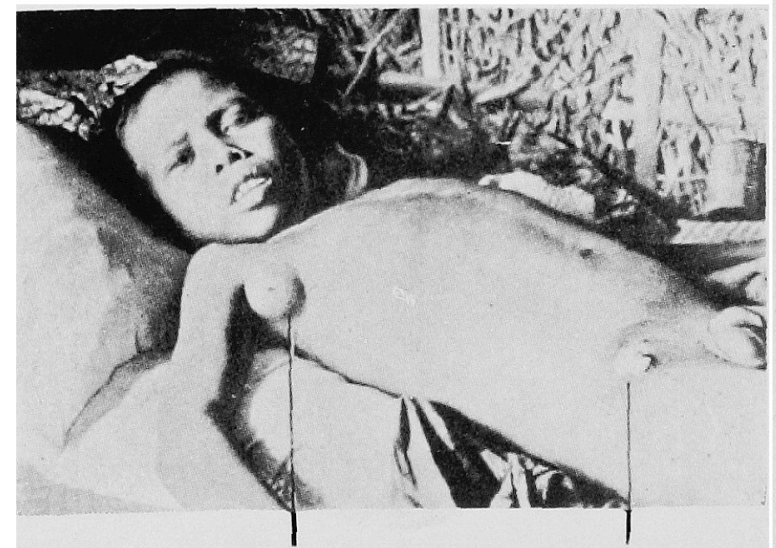

す示老脸脽の腙巴淋名よにト大へ腺

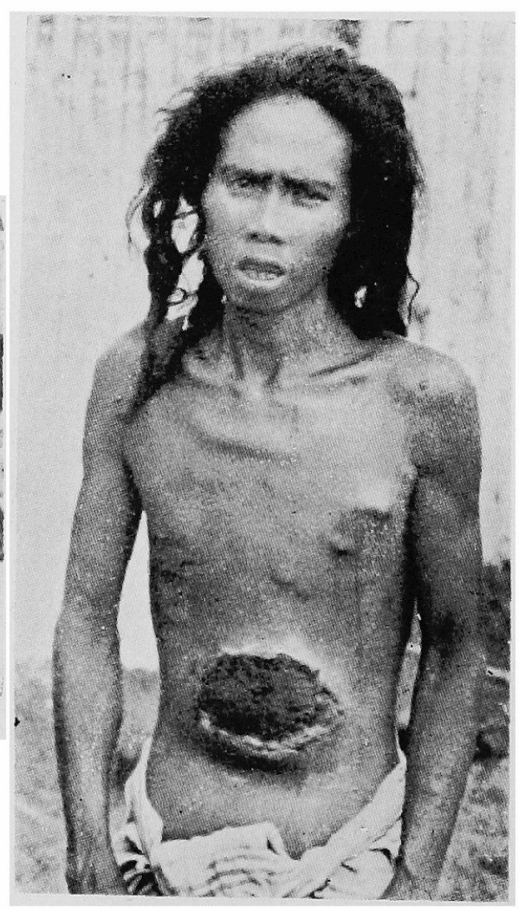

䟞變のトスペ膚皮 